\title{
SIR JOHN SALMOND AND MAORI LAND TENURE
}

\section{R P Boast ${ }^{*}$}

This chapter is deals with Salmond's engagement with Maori land issues, principally in his capacity as counsel to the Law Drafting Office and while Solicitor-General. Salmond appears to have had firm views on the extent of Native title in New Zealand, arguing either that all land vested in dominium in the Crown on the acquisition of British sovereignty, or, as a kind of fall-back position, that there were at least some parts of the Dominion, such as navigable lakes or the foreshore, where native title could not be asserted in any circumstances, not even in the Native Land Court. While it is tempting to conclude that Salmond's views were nothing more than the orthodoxy of the day, this paper argues that matters were more contested than is sometimes thought. Salmond developed considerable expertise in the technicalities of Maori land law, an expertise developed initially in the drafting of the Native Lands Bill of 1909 and which is reflected in various opinions he prepared while Solicitor-General and in his famous dissenting judgment in Boyd v Mayor of Wellington.

\section{INTRODUCTION}

Perhaps in no other area is there a greater risk of exploring Salmond's influence anachronistically than in the area of his engagement with Maori land questions. In Southern Jurist Professor Frame has already explored Sir John Salmond's engagement with legal questions pertaining to the Maori people, focusing in particular on the Lake Rotorua case, a cause célèbre of the day, and one in which Salmond played an important role as Solicitor-General - although he did not, in fact, present the whole of the Crown case before the Native Land Court. ${ }^{1}$ My aim here is essentially the modest one of providing some additional details and supplementing the picture that Professor Frame has already painted for us. Since the publication of Southern Jurist a great deal of additional research has been done on the Native Lands Bill 1909 and on some key Maori cases and claims during Salmond's tenure of office as Solicitor-General, including the Rotorua lakes affair in particular. This chapter takes account of this material and attempts to reassess the overall

* Associate Professor, Faculty of Law, Victoria University of Wellington. This chapter was written before I had the benefit of reading Mark Hickford's detailed essay printed in this volume, which covers in comprehensive detail many of the issues addressed here.

1 Alex Frame Salmond: Southern Jurist (Victoria University Press, Wellington, 1995). 
siginificance of Salmond's contribution. In my view it is a contribution which should not be exaggerated unduly.

It is very clear that Salmond knew a great deal about statutory Maori land law - evidenced by the analytical quality of his dissenting judgment in Boyd $v$ Mayor of Wellington ${ }^{2}$ and his penetrating, if compressed, review of Maori land legislation reprinted in the first consolidated edition of the New Zealand Statutes. ${ }^{3}$ Salmond also played an important role with regard to a number of cases and issues relating to lakes, the foreshore and water bodies generally. He appeared for the Crown in the key decision in Tamihana Korokai ${ }^{4}$ and was subsequently influential in developing the Crown case in the Rotorua lakes inquiry in the Native Land Court. Salmond also played an important role in the litigation relating to Lake Waikaremoana, and on a number of occasions wrote highly influential opinions relating to such questions as Maori title to the foreshore, the Mohaka-Waikare blocks in Hawke's Bay, and other issues of the day. While, however, Salmond knew a great deal about the law, there seems to little or no evidence that Salmond was intellectually interested in Maori history and culture as such, that he had any significant contact with the Maori world, or was in any way drawn to the study of Maori customary law. This is not being anachronistic: there were judges and practitioners at the time who were interested in Maori customary law and who wrote dissertations and books about it.

As noted, the legal universe of Maori land law was a field that Salmond thoroughly mastered. The legal history of statutory Maori land law is, however, still something of a Cinderella subject in New Zealand historiography. The consensus of the historical profession seems to be that the Native Land Court was A Bad Thing, as were the Native Lands Acts that defined its powers and controlled its jurisdiction. Much has been written about the Land Court itself, rather less about the legal history of the Native Lands Acts, and virtually nothing about the veritable mountain of case law that the Acts generated (about, for instance, such matters as the ability of holders of memorials of title under the Native Lands Act 1873 to maintain actions in trespass, enter into contracts, or avail themselves of insolvency legislation). ${ }^{5}$ Nor have the judges of the Court attracted much scholarly attention,

2 Boyd v Mayor of Wellington [1924] NZLR 1174 (CA). I am referring here not to Salmond's famous defence of "deferred" indefeasibility under the Land Transfer Acts but rather to his analysis of the factual background to the Privy Council's decision in Assets v Mere Roihi [1905] AC 176; (1905) NZPCC 275.

3 Salmond "Notes on the History of Native-Land Legislation" in Public Acts of New Zealand (Reprint) 19091931 (vol 6, Butterworth, Wellington, 1932) 87-94.

4 Tamihana Korokai v Solicitor-General (1912) 32 NZLR 321 (CA); (1912) 15 GLR 45.

5 See for example In re Henare Potae, Ex P Cattell and Buckley (1882) NZLR 1 SC 214 (memorial of title and bankruptcy); Tinline $v$ Mackay (1882) NZLR 1 SC 181 (validity of agreement between surveyor and owners under memorial of title; effect of Native Lands Act 1873, s 87); Creditors' Trustees of Arekatera Te Wera $v$ Walker (1884) NZLR 3 CA 9 (alienation provisions of 1873 Act); $R v$ Harrison (1884) NZLR 3 SC (payment of Māori land duty); In re Koatrepaia Block (1884) NZLR 3 SC 54 (alienation under 1873 Act); Mangakahia $v$ New Zealand Timber Co Ltd (1884) NZLR 2 SC 345 (whether owners under memorial can maintain action in trespass); Sutton $v$ Sheehan (1884) NZLR 3 CA 46 (combined effects of 1873 and 1880 
although they included some very interesting people amongst their ranks. Even less has been written about the intellectual history of the debate over Maori land and sea tenure, the assumption being that there was no debate to speak of and nothing interesting to discuss. That, as I hope to show in this paper, was far from the case. Complexities have sometimes been smoothed away by "the Crown has been very naughty" school of New Zealand history. While the lines of contemporary debate are still unclear, and require a lot more research, there certainly was debate, and it is a mistake to simply assume that Salmond's views on this subject were representative of his time.

\section{THE NATIVE LANDS ACT 1909}

Salmond's first major encounter with Maori land law appears to have resulted with his work on the legislation that was to ultimately enacted as the Native Lands Act 1909. Professor Frame discusses Salmond's role with regard to the Native Lands Act 1909 in Southern Jurist. ${ }^{6}$ At the time Salmond was Counsel to the Law Drafting Office. There is still much that is unclear about exactly how this influential statute was put together. The key architect of the reform was not Salmond, but rather the Liberal Native Minister, Sir James Carroll (Timi Kara) and his parliamentary undersecretary, Apirana Turupa Ngata. Nor should the importance of the 1909 Act be over-emphasised. Dr Frame has stated that the 1909 Act "involved the recasting of the basic concepts of New Zealand law relating to Maori land". ${ }^{7}$ The Act certainly consolidated the law and was in that sense a monumental achievement. It introduced a very useful reform (the meeting of owners process, from which the Crown soon exempted itself, as it happens). But a "recasting" of "basic concepts"? That is arguable, as I hope to show.

Salmond saw the Native Lands Acts as one of the two main means of extinguishment of Maori customary title to land in New Zealand, the other being, of course, "the voluntary cession to the Crown of lands purchased from the Native customary owners". ${ }^{8}$ He characterised the function of the Native Land Court as: ${ }^{9}$

ascertaining the title to customary land, whereupon a Crown grant or a certificate of title under the Land Transfer Act is issued to the Native owners. The land so dealt with, though it continues to be owned by the Native proprietors, ceases to be held under the Native title, and becomes freehold land held under English tenure in fee-simple from the Crown.

Acts); Ani Kanara v Mair (1885) NZLR 4 SC 216 (conclusiveness of memorial of ownership). These cases are but a fraction of a vast total.

6 Frame, above n 1, 111-116.

7 Ibid, 111

8 Salmond "Notes on the History of Native-Land Legislation", above n 3, 87.

9 Ibid. 
Here Salmond summarises the effects of the Native Land Court with his usual clarity and concision of expression. In 1862-65 New Zealand had embarked on a radical policy of jettisoning Crown pre-emption and conferring on Maori a right of freedom of alienation once their land had been investigated and Crown-granted. The initial plan had been for the state to withdraw from the Maori land market, Crown pre-emption being waived in the preamble to the 1862 Native Lands Act. In the 1870 s, however, policy changed again, and the Crown returned to Maori land purchasing on a massive scale, protecting itself with a complex array of pre-emptive powers that was one factor in leading to an almost impossibly complicated array of statutes by the early $20^{\text {th }}$ century.

Salmond may have drafted the 1909 legislation but his role seems to have principally been that of a technician, albeit a highly-skilled one who would have had to familiarise himself with a great deal of complex statute law. In a recent study of the history of Maori Land Boards Dr Donald Loveridge has considered the development of the 1909 Native Lands Bill in detail. ${ }^{10}$ Loveridge notes Salmond's "very important contribution" but emphasises, clearly correctly, that "he [Salmond] had a good deal of help, and the key decisions which had shaped the legislation were made elsewhere". ${ }^{11}$ Salmond was simply not in position as Parliamentary draftsman to make important decisions of policy. Loveridge emphasises that the principal context for the 1909 legislation was the work of the Stout-Ngata Commission of 1907-8. To a large extent the legislation set in place reforms proposed earlier by Stout and Ngata in their various reports. Sir Robert Stout and the young Apirana Ngata had been appointed in January 1907 to form a Royal Commission required to investigate and report on Maori land. The specific terms of their commission need not detain us, although it is relevant to note that from the point of view of the government the purpose of the commission was essentially one of identifying what Maori land remained unoccupied and available for settlement. ${ }^{12}$ The Commissioners were able to transcend their terms of reference to some extent, and expressed quite trenchant opinions on, for example, how the Crown had gone about purchasing lands from Maori in the King Country at below market values. Land purchasing practice by government officials was, in fact, a very significant issue and one of vital importance to Maori communities. A key problem was the inability of owners collectively to prevent individuals from

10 Donald Loveridge Maori Land Councils and Maori Land Boards: An Historical Overview, 1900-1952 (Unpublished report to the Waitangi Tribunal, Wellington, 1996). Loveridge argues that Professor Frame's Southern Jurist gives "the impression that the 1909 Act was largely his [Salmond's] own work", whereas in fact "there was a good deal more to it than this" (ibid, 95). I am not sure that Professor Frame does mean to suggest that the legislation was largely Salmond's work; certainly that was not the case.

11 Ibid, 97.

12 The terms of reference of 21 January 1907 are set out in Stout and Ngata's Interim Report of the Commission appointed to Inquire into the Question of Native Lands and Native-Land Tenure [1907] AJHR G-1, i-11 (see analysis by Loveridge, ibid, 65). 
selling undivided shares to government land purchase officers, leading ultimately to partition and the imposition of costly survey liens in the Native Land Court. ${ }^{13}$

The Commissioners also referred on a number of occasions to the needlessly complex state of the statute law relating to Maori land and seem to have embarked on a first attempt to consolidate the law themselves. They quickly came to the conclusion that much more than a mere consolidation was required: ${ }^{14}$

In our opinion ... the Native Land Acts cannot be consolidated in the proper sense. There are so many conflicting provisions, so many sections worded in a general way, yet passed for temporary and special purposes, that consolidation, properly so-called, would be impossible. ... What is required is an Act or a number of Acts repealing existing general enactments and re-enacting same with necessary amendments.

Stout and Ngata were not, however, calling for a radical change to the core concepts underpinning the Native Lands Acts - nor did that ever eventuate.

In early 1909 Ngata became Carroll's under-secretary. The Royal Commission was reconstituted with Jackson Palmer, Chief Judge of the Native Land Court, serving as Ngata's replacement. One of Ngata's main responsibilities seems to have been that of liaising between Carroll and Salmond, who was entrusted with the technical responsibility of analysing the existing statute law and drafting. Loveridge considers that Ngata would have played a key role at the early stage of the drafting "when fundamental decisions had to be made concerning the format and contents of the proposed Bill". ${ }^{15}$ There is nothing to indicate that Salmond himself up to this point had any pronounced views on Maori land law or Maori policy - and thus it seems to be the case that the 1909 project was in fact his first introduction to the subject. Carroll and Ngata, by contrast, had been pondering the problems of Maori land policy for many years, and Sir Robert Stout had also had a long engagement with the subject both as a prominent Liberal politician and then as Chief Justice. One need not downplay Salmond's role in order to recognise that the primary architects of the reform were other people.

13 The government's Māori land purchasing programme in the period from 1870-1920 is analysed fully in my Buying the Land, Selling the Land: Governments and Maori Land in the North Island 1865-1921 (Victoria University Press and Victoria University of Wellington Law Review, Wellington, 2008). Numerous commissioned research papers prepared for the Waitangi Tribunal inquiry process have examined aspects of the system in detail. These include R P Boast The Crown and Te Urewera in the Twentieth Century: A Study of Government Policy (Research Report Commissioned by the Waitangi Tribunal, Wai 894, Doc\#A109, 2002) [Urewera Inquiry]; D M Loveridge The Development of Crown Policy on the Purchase of Maori Lands 1865-1910 (Report to the Crown Law Office, Wai 1200, Doc\#A77) [Central North Island Inquiry]; Bruce Stirling Taupo-Kaingaroa Nineteenth Century Overview (Research Report Commissioned by the Waitangi Tribunal, 2 vols, Wai 1200, Doc\#A71, 2004) [Central North Island Inquiry].

14 Stout-Ngata Commission Final Report [1909] AJHR G-1G, 8, cited in Loveridge, above n 9, 94.

15 Loveridge, ibid, 95. 
By September the Law Drafting office had produced a draft bill. In September the judges of the Native Land Court and the Presidents of the Maori Land Boards - the same people, more or less came to Wellington at Carroll's invitation and spent three weeks analysing and commenting on Salmond's draft. ${ }^{16}$ There was then a second conference with the judges, and after the Bill was introduced into Parliament it was scrutinised once again by the Native Affairs Committee, of which Carroll and Herries, the Opposition spokesman on Native Affairs, and later Native Minister, were both members. The Bill received bipartisan political support as the work of experts and was steered through Parliament by Carroll. It was, in short, the work of many hands. Salmond's technical and drafting expertise certainly played a role, and both Carroll and Herries praised Salmond for his work. In the House Herries was in accord with Carroll in a "word of hearty praise for to the Counsel for the Law Drafting Office and the Law Draftsman for the way in which they have accomplished this stupendous work". ${ }^{17}$

The 1909 Act certainly was a monumental achievement. But it did not change the core structure of statutory Maori land law. The key institution of the Maori land system, the Native Land Court, which had been in existence since 1865, was retained in its familiar form, although by this time its primary investigation of title function was more or less spent. ${ }^{18}$ Appeals from the Court went to a Native Appellate Court, which had been established in $1894 .{ }^{19}$ The core concepts of Maori customary and Maori freehold land remained as before. There was no new departure. The 1909 Act brought to an end the controlled experiment in restricted alienation that had begun in 1899 and reopened Maori land buying to the private sector, but that can hardly be described as innovative. The most important and beneficial reform contained in the 1909 Act from the viewpoint of Maori owners was a new procedure relating to owners' meetings, which at least returned some measure of control to Maori communities with regard to the land alienation process. This very useful reform was, however, taken out of the legislation by the Reform Government with the Native Land Amendment Act 1913, which lost no time in removing provisions that got in the way of its own expanded programme of Maori land acquisition. ${ }^{20}$ The 1909 Act did not in any way restrain the

16 See James Carroll's speech at (1909) 148 NZPD 1100, cited in ibid, 96.

17 Ibid.

18 Or so it was thought until the decision of the Court of Appeal in Attorney-General v Ngati Apa [2003] 3 NZLR 643 (CA).

19 In my view those who focus on the Native Land Court per se as the motor of Māori land alienation in the period from 1869-1921 are looking in the wrong place. Far more significant in this regard was the Crown land purchasing system which was in effect a statutory monopoly operating at a number of levels.

20 After 1909 TW Fisher, the Permanent Head of the Native Department, had become increasingly frustrated by Crown purchase offers being thrown out at owners' meetings. In the 1913 Annual Report of the Department Fisher pressed for exemption of the Crown from this process, and s 109 of the 1913 Act allowed the Crown to buy whatever Māori freehold, trust and reserve land it wanted. This led to a massively expanded purchase programme from 1913-1920. See Boast Buying the Land, Selling the Land, above n 13, 231-9. 
Reform Government's acquisition of nearly a million acres of Maori land in the period from 19121920, the last great round of government Maori land acquisition and in many ways the most damaging of all. Salmond was not, of course, an architect in any way of government land purchasing policy, but the 1909 Act did contain an abundance of powers for the government to target particular blocks, exclude the private sector and in essence force owners to sell land either on the government's terms or not at all. Salmond had good reason to proud of his contribution, and it can be no accident that when he later became a judge he was very critical of the Reform government's 1913 amending Act, which repealed and altered a number of the key provisions of the 1909 enactment.

\section{SALMOND AS SOLICITOR-GENERAL}

As Solicitor-General Salmond was naturally asked to provide advice on complex questions relating to Maori land law and the interpretation of the relevant statutes, advice which he gave with his customary clarity.

One important issue, for example, that came to Salmond's attention was the peculiar status of the Mohaka-Waikare blocks in Hawke's Bay, confiscated under the New Zealand Settlements Act and then (mostly) returned to Maori by agreement, but for which the necessary Crown grants and surveys had never been done. ${ }^{21}$ The status of these blocks was a key problem, and there had already been substantial litigation over one of them, Kaiwaka, litigation which had ended up in the Privy Council. ${ }^{22}$ The issue that Salmond was asked to deal with had arisen following a meeting of owners pursuant to the 1909 Native Lands Act regarding a different Mohaka-Waikare block, Purahotangihia. A number of legal points had been raised about the status of the blocks and following this the Native Department referred the matter to Crown Law. Salmond thought the position of these blocks to be "a somewhat extraordinary one". ${ }^{23}$

According to the Privy Council decision in Teteira $v$ Tereha [sic] the land has been effectually confiscated, the Native title effectually destroyed, and the land vested in the Crown. No Crown grant however has been issued. Therefore the land remains vested in the Crown subject only to a statutory

21 For a full analysis of the highly involved history of these blocks see RP Boast The Mohaka-Waikare Confiscation (Unpublished research report commissioned by the Waitangi Tribunal, 2 vols, Wai 201, Doc\#J28, 1995) [Mohaka ki Ahuriri Inquiry]. Salmond's opinions and their context are discussed in detail at pages 154-56. The Waitangi Tribunal reported on Wai 201 in 2004: see Waitangi Tribunal, The Mohaka ki Ahuriri Report: Wai 201 (Legislation Direct, Wellington, 2004).

22 Teira Te Paea and others v Roera Tareha and another (1896) 15 NZLR 91 (CA); Te Teira Te Paea and others $v$ Te Roera Traeha and another [1902] AC 56 (PC). The Māori plaintiffs failed in both the Court of Appeal and the Privy Council, following which they lodged a petition with King Edward VII. Sir Robert Stout was involved in this case as counsel for the defendants (also Māori).

23 Salmond "Opinion of 18 April 1914" copy on MA 1, 5/13/132, Archives New Zealand, Wellington. 
power and obligation on the part of the Governor to issue a grant. The result is that the land is not Native land at all.

Salmond was certainly correct about the legal status of the Mohaka-Waikare titles. The problem with these blocks, however, was that on the erroneous assumption that they were Maori freehold land the Native Land Court had made numerous succession and partition orders in respect of them which were all technically void. Salmond concluded that the only way out of the mess was to give to the Native Land Court a special jurisdiction to ascertain relative interests in the blocks and for the void Land Court orders to be validated by statute, which was by section 4 of the Native Land Claims Adjustment Act 1914. Salmond here ably diagnosed a complex legal problem and proposed a practical and workable solution. Following the enactment of the 1914 legislation the MohakaWaikare blocks were mostly rapidly reacquired from their Maori owners by Crown undivided sharebuying and partition.

Salmond was a prominent Crown official and certainly gave advice which allowed the Crown to cut legal corners as a part of its Maori land purchasing policy. An example of this are the complications arising out of the government's efforts to buy up Maori land interests in the Te Whaiti 1 and 2 blocks (in the Urewera region). These two large blocks were owned by Ngati Whare and Ngati Manawa respectively, and purchasing began in 1915. Both blocks contained valuable stands of native forest, with a great deal of millable totara, rimu, matai and kahikatea. ${ }^{24}$ Purchasing followed the usual pattern, a rapid acquisition of most of the Maori shares almost immediately, and then a gradual slow-down. By October 1917 the Native Department had acquired 58 per cent of the interests in Te Whaiti 1 and 82 per cent of Te Whaiti 2. It did not manage to get a complete title to either, and in fact the purchasing process was not finally resolved until the completion of the Urewera Consolidation scheme in 1927.

In late 1917 some of the non-sellers began cutting timber on the Te Whaiti blocks. The Commissioner of Crown Lands at Auckland was very annoyed about this when he got to hear about it, and urged his department to take out injunctions in the Native Land Court to prevent all timbercutting. ${ }^{25}$ CB Jordan, Under-Secretary of the Native Department, was equally annoyed, but was uncertain as to the legal position. Would the Court even give the government an injunction? There was some uncertainty as to why the timber was cut, who was cutting it, and whether it was being cut for sale to sawmillers or for building a meeting-house. At this point Jordan obtained an opinion from Salmond who advised that while "there is nothing illegal in the act of a joint owner using the land and deriving profit therefrom even by cutting timber or mining", anyone making a profit in this way

24 "R C Pollock (Lands Department) to Commissioner of Crown Lands, Auckland, 2 August 1915", MA-MLP 1, 10/28/4, and F 1, 9/1/13, Archives New Zealand, Wellington.

25 "Commissioner of Crown Lands, Auckland, to Under-Secretary of Lands, Wellington, 1 October 1917", MA-MLP 1, 10/28/4, Archives New Zealand, Wellington. 
is "bound to account to their co-owners, so that the profit may be divided between them in proportion to their interests". ${ }^{26}$ This was simply to state the ordinary law.

Salmond added, however, that the government might get an injunction from the Land Court preventing all timber-cutting provided that an application for partition was made at the same time. The Native Department was not very happy with this proposal. It was still quite early in the purchasing programme, far too early to apply for a partition. On the other hand, without applying for a partition the government would be very unlikely to get an injunction. After pondering the problem for a month or so the Native Department adopted Salmond's suggestion, but proceeded on the subterfuge of lodging a pro forma partition application while at the same time essentially instructing the Court to immediately lose it behind a filing cabinet. Jordan forwarded applications for partition and injunction to the Court at Rotorua but directed the Registrar to shelve the partition application, as "it is not desired that the Crown's applications for partitions should be set down for hearing just yet". The application for an injunction, however, "should be heard at the earliest possible date". ${ }^{27}$ This allowed the government to essentially have its legal cake and eat it too. The Native Department treated the whole affair with great seriousness, going so far as to request the local policeman at Te Whaiti "to warn the Natives that the Crown is taking immediate action" and to ask Native Department staff to find out to whom the timber was being sold. ${ }^{28}$ Eventually the Crown was able to obtain the prized Te Whaiti forests, which it later proceeded to cut down.

This example has been selected to show the complexities of government Maori land-purchasing at this time and to illustrate Salmond's role, which was simply that of the Crown's legal adviser. There is nothing surprising or unexceptionable in this, needless to say, except that it is important to remind ourselves of the principal context in which Salmond was engaged with Maori land: as an astute legal adviser, watchful of the Crown's best interests and somewhat at a remove from the mundane realities of land acquisition.

\section{NATIVE TITLE AND LAKES}

A key question in New Zealand legal history, perhaps the key question, is the nature of the Crown's title acquired on the point of the acquisition of sovereignty in 1840. This is discussed by Professor Frame in that part of Southern Jurist which deals with the Rotorua lakes litigation, in

26 "Solicitor-General [Salmond] to C B Jordan, 10 October 1917", MA-MLP 1, 10/28/4, Archives New Zealand, Wellington.

27 "C B Jordan to Registrar, Waiariki District Native Land Court, 17 November 1917", MA-MLP 1, 10/28/4, Archives New Zealand, Wellington.

28 "Under Secretary, Native Department, to Bowler, 17 November 1917", MA-MLP 1, 10/28/4, Archives New Zealand, Wellington. Constable Grant was requested to "as soon as possible warn the Natives of the action being taken by the Crown, so that they may realise the need for at once stopping further cutting": "Under Secretary, Native Department [CB Jordan] to Constable Grant, Te Whaiti, 20 November 1917", MA-MLP 1, 10/28/4, Archives New Zealand, Wellington. 
which Salmond as Solicitor-General acted for the Crown both in the ordinary courts and in the subsequent proceedings in the Native Land Court. ${ }^{29}$

Before the Native Land Court Earl KC stated what I think can be taken to be the modern position, that on the acquisition of sovereignty "the Crown acquired nothing but what could be voluntarily ceded [sic] to the Crown or purchased". Professor Frame notes this statement was annotated (by Salmond) to the effect that "Acquired the whole dominium subject to Native proved titles", a view which was consistent with remarks made in Salmond's textbook on Jurisprudence: "[w]hen New Zealand became a British possession, it became not merely the Crown's territory, but also the Crown's property, imperium and dominium being held concurrently". ${ }^{30}$ Professor Frame argues that Salmond's position is "as modern as Mabo", ${ }^{31}$ a proposition that I must confess to having some difficulty with, especially in view of the fact that Salmond also insisted that Native title was only in force only because it had been given effect by statute law. Salmond's position appears, rather, to be identical to that of the Court of Appeal in In re the Ninety Mile Beach - which has now of course been overruled by the Court of Appeal in its turn. ${ }^{32}$ (The Court of Appeal's overruling has been in its turn overruled by the government. ${ }^{33}$ It seems to me that there is a world of difference between sourcing Native title rights in the common law and sourcing them in statute, a distinction which Professor Frame here seeks to minimise but which, with respect, seems to me fundamental.

It might be said that in taking the stance that he did, Salmond was reflecting only the legal orthodoxy of the day, but I am not so sure. Intellectual debate on legal and constitutional fundamentals in early twentieth-century New Zealand may have been more lively than is sometimes supposed. Indeed the intellectual history of New Zealand generally is still unexplored terrain, let alone the history of such sub-topics as the debate on Maori land tenure. Salmond's position may have been the dominant one at Crown Law and amongst the upper levels of the judiciary, but there was also a counter-tradition, exemplified by some members of the bar (Earl KC, for one, and $\mathrm{CB}$ Morison for another), and by the judges of the Native Land Court. ${ }^{34}$ Salmond can be contrasted

29 Frame, above n 1, 108-132.

30 John Salmond Jurisprudence: or the Theory of the Law (7 ed, Stevens \& Haynes, London, 1924) 554, as cited in ibid.

31 Frame, above n 1, 108.

32 In re the Ninety Mile Beach [1963] NZLR 461 (CA); Attorney-General v Ngati Apa, above n 18. See generally RP Boast Foreshore and Seabed (LexisNexis, Wellington, 2006).

33 By the Foreshore and Seabed Act 2004. Section 13 of this Act vests all public foreshore and seabed absolutely in the Crown. Perhaps Salmond would have felt vindicated by this statute, although because of its impenetrable verbosity one hopes not. Salmond believed in simplicity and clarity in legal drafting.

34 The judges of the Maori Land - an underestimated group in New Zealand legal history in my view - were, of course, working within the statutory framework of the Native Lands Acts, rather than being concerned with Native/aboriginal title issues in the Courts of Common Law. 
with the equally talented Frank Acheson, who wrote an LLM thesis on Maori customary law in 1913 while working as a legal clerk at the Native Department, ${ }^{35}$ and who later became judge of the Wanganui and then of the Tai Tokerau division of the Native Land Court. In his thesis Acheson argued that Maori certainly did have an ascertainable body of legal custom. He also wrote a number of law review articles on related topics which were published overseas, and issued a number of important judgments in the Land Court on foreshore and lakes which are identical to the current position on Native title and the acquisition of the Crown's sovereignty. Acheson was not unique. In 1920 Chief Judge Jones was in no doubt that Maori customary title could include the foreshore and seabed, a proposition to which Salmond was opposed. Chief Judge Shepherd and his colleagues threw out the Crown appeals relating to Lake Waikaremoana in $1944 .{ }^{36}$ In Waikaremoana the Native Appellate Court had no hesitation in stating that "in New Zealand the rights of the Natives are safeguarded without reference whatsoever to the incidents of English law" and that Maori "successfully established their title to Lake Waikaremoana once they satisfy the Court it was held by them in accordance with their customs and usages and unless it be shown that this title has been extinguished". ${ }^{37}$ It is that statement which can perhaps be more convincingly be said to be "as modern as Mabo". Chief Judge Morison, who gave the Maori Land Court judgment - in favour of the Maori claimants - in In re Ninety Mile Beach, stands very much in the Acheson tradition. (Interestingly this intellectual tradition has persisted in the Maori Land Court, as exemplified by Judge Hingston's decision in the Marlborough Sounds case, reversed by the High Court but, of course, upheld by the Court of Appeal. $)^{38}$ In noting all this, I do not mean to create a Whig version of New Zealand history and award the palm to those who fit more closely with current opinions; the point is rather that there was a significant range of opinion on Maori title issues amongst the legal profession and the judiciary. Salmond's view was precisely that: a point of view - one that not everyone would have accepted.

It is clear that Salmond opposed quite vigorously any suggestion that Maori could claim customary title to the foreshore or seabed or to large inland water bodies such as Lake Wakatipu or Lake Waikaremoana. One can take the point that it is important to separate Salmond's professional advice as Solicitor General and his opinions as a scholarly jurist, but in this regard at least it is the case that Salmond had a developed position on native title articulated consistently in his opinions and legal submissions. As a practising barrister myself, I might add that in my own experience is

35 FOV Acheson "The Ancient Maori System of Land Tenures (Some Few Aspects of)" (Thesis written for Jacob Joseph Scholarship, Victoria University College, Wellington, 1913).

36 See (1944) 8 Wellington ACMB 30. There is a copy of the Appellate Court's Waikaremoana decision on CL 200/16, Archives New Zealand, Wellington.

37 Ibid.

38 See Marlborough Sounds (1997) 22A Nelson MB 1; Attorney-General v Ngati Apa [2002] 2 NZLR 661 (HC). 
that is difficult, if not impossible, to separate clearly one's intellectual and practising selves. Every now and then we put forward legal arguments we disagree with, but core concepts and ideas are a different matter. I find it hard to imagine that Salmond would put forward a set of consistent views on lakes and the foreshore elaborated over a number of years if he was not committed to them personally. In fact his opinions on these matters were developed ones, and were not merely legal points that he had to put forward on the Crown's behalf. That still leaves the reasons for Salmond's opposition to such claims to be worthy of serious consideration on their own terms, of course.

Salmond's views were based largely on a particular reading of New Zealand legal history. He was not persuaded that Maori owned the whole corpus of land and resources in the country as at the acquisition of British sovereignty in 1840, and therefore it did not follow that merely because it could be shown that a particular resource had never been alienated to the Crown the Maori customary title must be deemed not to have been extinguished, or that Maori still "owned" it today: ${ }^{39}$

Native title is not universal. It is not true that the whole of New Zealand, whether land or water, is necessarily the subject of Native title except so far as such title has been extinguished by cession,

forfeiture, or otherwise.

This proposition has some force, of course, although this is contentious (what do we make of some of the pleadings in the Waitangi Tribunal's current Wai 262 - Fauna and Flora claim - which do in fact assert that Maori did indeed own the entire corpus of New Zealand in 1840, including all of its fauna and flora and the intellectual property contained therein?) But in the case of lakes and the foreshore I would venture the opinion that Maori customary title must include those, or some of them at least, given the wealth of documentation that establishes the vital role of such water bodies in the Maori world. Salmond's strenuous opposition to such claims smacks somewhat of the dogmatic.

In general the Crown has been very reluctant to concede that Maori can have title to the beds of large navigable lakes (such as Taupo, Rotorua, Waikaremoana, Wairarapa and so on). This was a pronounced stance of Sir John Salmond and of the Crown Law Office. In an opinion written in 1914, relating to the Rotorua lakes, Salmond argued that it "is quite out of the question to allow freehold titles to be obtained by the Natives" to navigable waterways, including lakebeds: 40

Such titles would enable the Natives to exclude the whole of the European population from all rights of

fishing, navigation and other uses now enjoyed by them.

39 Citing the Crown legal submissions in the Rotorua Lakes case, written submissions on CL 174/2, Archives New Zealand, Wellington. Salmond either wrote these submissions himself, or at the very least played an important role in preparing them.

40 Salmond to Attorney-General, 1 August 1914, Crown Law Office Opinions relating to Lands Department 1913-1915, cited in Frame, above n 1, 110. 
In fact there is very little support for the notion that the Crown has any kind of prerogative title to lake beds at common law. According to Halsbury's Laws of England the "soil of lakes and pools, even when they are so large that they might be termed inland seas, does not of common right belong to the Crown". ${ }^{41}$ Kent McNeil's authoritative text on the law of native title states that only the foreshore and related waters are deemed to belong to the Crown: ${ }^{42}$

Unlike other lands in the realm, the foreshore and the beds of tidal rivers and coastal waters are presumed and coastal waters are presumed to be owned by the Crown by prerogative right.

There is, then, no common law presumption of Crown ownership of lakebeds.

One possibility is that Salmond's views may have been affected by United States law. In the United States the position is that ordinarily title to navigable waterways, including lakebeds, vests in the various states except on those rare occasions where the Courts are prepared to find that Congress intended to grant the bed of a navigable watercourse to a tribe when creating a reservation. ${ }^{43}$ The ordinary presumption of state title in American law is rebutted in those circumstances where a grant to an Indian tribe "includes within its boundaries a navigable water" where the tribe is known to be "dependent on the fishery resource in that water for its survival". ${ }^{44}$ The approach of American law on the point is probably influenced by the scale and importance of the great freshwater lakes and rivers of North America; it is safe to say that Indian title to Lake Michigan or the bed of the Mississippi River was not an appealing prospect to the government of the United States. The existence of very large inland water bodies in New Zealand, such as Lake Taupo, far bigger than anything to be found in England, would presumably have influenced Salmond's thinking on the matter as well.

The leading New Zealand case on lakebeds is the 1912 decision of the Court of Appeal in Tamihana Korokai $v$ Solicitor General in which Salmond appeared for the Crown. ${ }^{45}$ This case which arose out of the Rotorua lakes title investigation case in the Native Land Court - held that the Native Land Court had jurisdiction to investigate titles to the bed of navigable lakes. It probably follows from this that lakebeds have no particular status in New Zealand common law and that they

41 Halsbury's Laws of England (4 ed, vol 49, Butterworths, London, 1973) 219 cited in Ben White Inland Waterways: Lakes (Rangahaua Whanui Series, Waitangi Tribunal, 1998) 3.

42 Kent McNeil Common Law Aboriginal Title (Clarendon Press, Oxford, 1989) 103.

43 The general rule is set out in Montana v United States (1981) 450 US 544, a decision of the United States Supreme Court. The presumption of state ownership has however been found to have been rebutted in a sequence of Ninth Circuit Court of Appeals decisions, these being Confederated Salish and Kootenai Tribes $v$ Namen (1982) 665 F 2d 951 ( $9^{\text {th }}$ Cir); Puyullap Indian Tribe v Port of Tacoma (1983) 717 F 2d 1251 (9 $9^{\text {th }}$ Cir) and United States $v$ Aam (1989) 887 F 2d 190 (9 $9^{\text {th }}$ Cir).

44 Puyullap Indian Tribe v Port of Tacoma 717 F 2d 1251, 1258.

45 Tamihana Korokai v Solicitor-General (1912) 15 GLR 95. 
are simply Maori customary land until investigated by the Court and Crown-granted. However the Crown Law Office, led by Sir John Salmond, despite Tamihana Korokai, remained very reluctant to concede that lakebeds merely had the status of ordinary Maori customary land. In its legal argument before the Native Land Court in the Rotorua lakes case the Crown legal team tried to limit the application of the decision in Tamihana Korokai: ${ }^{46}$

In Tamihana Korokai $v$ Solicitor-General an attempt was made to get the Supreme Court to decide as a matter of law the legal position of the inland lakes and waters of this country. Unsuccessful. The Court decided merely that the Native customary title might exist in respect of such waters but that the question whether it does exist is a matter for the Native Land Court. A question of fact or mixed law and fact such that the Native Land Court could alone determine it on the facts of each particular case. Hence these proceedings.

Essentially the Crown stance, even after Tamihana Korokai, was that while Maori could be said to have title to small non-navigable lakes or waterways, Maori could not own, as a matter of law, large lakes such as Rotorua, Taupo or Waikaremoana, the principal criterion being whether the water body was "navigable". ${ }^{47}$ To cite, once, again, from the Crown submissions in the Rotorua case: ${ }^{48}$

It is admitted that some waters can be the subject of Native title and that freehold orders can be made in respect thereof. The question in issue relates only to navigable waters whether rivers or lakes. Unnavigable waters are mrely appurtenant to the adjoining land and go with it in title. It does not follow, however, that because some water is the subject of all native title all water is. Navigability is of course a question of degree. Water may be navigable for a canoe but not for a battleship ... In the meantime it is sufficient to say that contention of the Crown is limited to navigable waters.

What, however, are 'navigable' waters? It has to be wondered quite what the public interest in "navigation" in, for instance, Lake Waikaremoana might be - the lake is not and never was a major commercial artery. By Salmond's day it would only have been "navigated" by a few canoes and rowboats. In the Rotorua lakes case the Crown also argued, probably correctly, that freehold grants

46 Crown legal argument in Rotorua Lakes case, CL 174/2, Archives NZ, Wellington.

47 With respect to "navigability" as a criterion, Salmond would of course have been aware of the Court of Appeal's decision in Mueller v Taupiri Coal Mines Ltd (1900) 20 NZLR 89 (CA). The majority of the Court of Appeal had here held that the presumption that a Crown grant extended ad medium filum aquae was rebutted in the case of a military grant bounded by the Waikato river, partly because the river was used for the purposes of navigation. This had been subject, however, to a strong dissent by Stout CJ, and for the avoidance of doubt the government enacted the Coal-mines Amendment Act 1903, s 14(1) of which vested the beds of "navigable" rivers in the Crown. This provision is still in force as s 354 of the Resource Management Act 1991. No such general legislation was ever enacted with respect to lakebeds. 
bounded by the lakeshore did not extend to the centre of the lake on the ad medium aquae rule. ${ }^{49}$ The lake, therefore, could only be either Crown land or Maori customary land. In Salmond's view it could only be the former.

In November 1918 the presiding judge in the Rotorua inquiry, Judge Wilson, died of influenza and the Court never reconvened to complete the case, despite a number of requests by claimant counsel (Earl) to have the hearings proceeded with. ${ }^{50}$ Salmond must have been pondering some way to have the case reheard de novo, a proposal which provoked considerable irritation on the part of the Department of Lands, at least if the following memorandum is any indication: ${ }^{51}$

It's all very fine for your Chief to say don't do this or that. Any one could say as much. Why doesn't he tell us exactly what to do. Apparently he is relying upon tiring the Natives out and so disheartening them with delay and expenses that they will at length chuck up the sponge. He seems to be trying to bluff them that he has a royal flush. That de novo stunt of his is staggering - what about us poor blighters having to go through this again.

Native and Lands Department staff had clearly not enjoyed the experience of being crossexamined by Earl KC before the Native Land Court.

Salmond was convinced by this time that the Crown was going to lose the case in the Native Land Court and that for this reason it could not be allowed to proceed. Salmond wanted the issue kept away from the Native Land Court, which can be said to be forward-looking in a way. An unwillingness to allow the Native/Maori Land Court to have the opportunity to adjudicate on matters of political concern to governments has been a pronounced feature of Crown policy down to the present day, as the Foreshore and Seabed Act 2004 exemplifies perfectly.

In April 1920 Salmond informed the Under-Secretary of the Department of Lands that it was "advisable" that "the continuance of this [Rotorua] litigation be put to an end if possible by some settlement with the Natives". Salmond could see what was going to happen: ${ }^{52}$

49 Ibid: "No existing freehold title to Lake Rotorua. This is common ground. The boundary of the freehold titles is the edge of the lakes. The presumption as to ad medium filum is merely a presumption and is easily capable of rebuttal. Taupiri Coal Mines Company v Mueller. It may be doubted indeed how far it applies to a lake at all owing to the irregularity in its shape and the impossibility of saying what the medium filum is. In any case, it is rebutted where the grant of freehold consists of or is based upon a freehold order. The freehold title cannot extent further than the land investigated by the Court. Non constat [I do not dispute] that if the Lake is owned by the Natives at all it is owned by the same Natives as those who own the adjoining land. It may be taken as admitted therefore that the Lake is either Native customary land or Crown land free from Native ownership."

50 White, above n 41, 116.

51 Knight, Lands Department, Auckland, to Prenderville (Crown Counsel), 21 October 1919, CL 174/2, Archives New Zealand, Wellington, cited in ibid. The reference to "your Chief" is clearly to Salmond.

52 Salmond to Under-Secretary of Lands, 29 April 1920, CLO Opinions (vol 7, LINZ) cited in ibid. 
I think it is probable that the final result of the litigation will be the making of freehold orders by the Native Land Court giving them title to these lakes as being Native freehold land. As a matter of public policy it is out of the question that the Natives should be permanently recognised as the owners of the navigable waters of the Dominion. It would not seem to be a matter of serious difficulty to avoid this result by making some form of voluntary settlement with the Natives and by vesting these Lakes by Statute in the Crown.

Salmond's strategy was the one the government adopted, although of course it is certainly probable that other people within government were thinking along similar lines. The full history of the Rotorua lakes negotiations has been traversed in detail by Ben White. ${ }^{53}$ Salmond had been appointed to the Bench by the time the negotiations began, which were dominated by Earl (counsel for Te Arawa), R Knight of the Department of Lands, Sir F D Bell, the Attorney-General, Prenderville (Crown counsel) and Apirana Ngata. The negotiated settlement was given effect to by section 27 of the Native Land Amendment and Native Land Claims Adjustment Act 1922, which related to the "Arawa district lakes". It vested the beds of 14 lakes in the Crown, "freed and discharged from the Native customary title, if any" and set up the Arawa District Maori Trust Board which received income from the Crown and from fishing licences as agreed in the negotiations. It was a settlement that not all Te Arawa leaders were happy with. ${ }^{54}$

Salmond also played a role in the shaping of another lake case of the time, that relating to Lake Waikaremoana. ${ }^{55}$ Title to this beautiful lake in the Urewera region was contested between three Maori groups, these being Tuhoe, Ngati Ruapani, and some sections of Ngati Kahungunu. The boundary line between Tuhoe and Ngati Kahungunu was then, and still is, highly contested. These were not the only issues. Tuhoe regarded the lake as theirs, and resented Pakeha "sportsmen" being encouraged to fish in the lake by the Tourist Department. The government was also interested in the lake because of its hydroelectric potential. ${ }^{56}$

Despite these broader issues, the Waikaremoana case was, unlike the Rotorua case, much more of a contest between Maori inter se than it was a legal battle between the Crown and Maori.

53 See White, ibid, 117-122.

54 Ibid, 122.

55 Professor Frame does not deal with the Waikaremoana case. On this see RP Boast, The Crown and Te Urewera in the 20 $0^{\text {th }}$ Century: A Study of Government Policy (Unpublished reports commissioned by Crown Forestry Rental Trust, Wai 894, Doc\#A109) [Urewera Inquiry] 273-302.

56 The decision to proceed with the construction of the Waikaremoana power scheme was taken in October 1919 following a meeting between a body called the Waikaremoana Hyrdo-Electric League and the Prime Minister (Massey). Construction began in 1926. 
Salmond was, however, concerned about it and referred to this case in an opinion written in 1917, where he dealt with both the Rotorua and Waikaremoana cases: ${ }^{57}$

The only course is to have these applications in respect of Lake Rotorua and Lake Waikaremoana heard by the Native Land Court. The Crown, however, should be present at the hearing and should dispute the right of the Natives to obtain freehold orders for the inland navigable waters of the Dominion. The question is of such importance that it would seem desirable that the case should not be heard before a single Judge but before a specially constituted court consisting of the Chief Judge of the Native Land Court and as many of the puisne judges as possible. The case should be heard in Wellington so far as regards the preliminary question as to whether freehold orders can be made at all.

Should the preliminary question go against the Crown, Salmond thought - and in view of the decision in Tamihana Korokai one might have thought that would have been more than likely - then perhaps "some arrangement" might be made with the Court: ${ }^{58}$

It ought to be possible, however, to make some arrangement with the Court by which, if the decision is against the Crown, the making of an actual freehold order can be deferred in order to give the government and parliament an opportunity of considering the whole question and making provision for the compensation of the Natives in lieu of the actual issue of freehold orders to the waters in question.

This indicates that Salmond did not rule out the possibility of some kind of compensable property right held by Maori with respect to "inland navigable waters". What he was anxious about was the risk posed by freehold grants to them. It would be interesting to know more about Salmond's general political leanings in order to assess this. ${ }^{59}$ Advanced Liberals of the stamp of John Ballance, Sir Robert Stout or Edward Tregear were likely to oppose such grants because of a belief in the importance of protecting the public estate. ${ }^{60}$ One assumes that was Salmond's take on

57 Salmond to Under-Secretary of Lands, 11 June 1917, CL 174/2, Archives New Zealand, Wellington.

58 Ibid.

59 Where did Salmond stand on the political spectrum? New Zealand in Salmond's era was a highly politicised society. One comes away from Southern Jurist with little sense of Salmond's politics, which might well indicate that he was comparatively apolitical. The best guide to politics in the Liberal era is David Hamer The New Zealand Liberals: The years of power, 1891-1912 (Auckland University Press, Auckland, 1988). No detailed study of the Reform government 1912-1927 has been written, another historiographical black hole in New Zealand literature.

60 Ballance and Tregear are both the subject of outstanding biographies full of insights into intellectual and political trends in the colony. See Timothy McIvor The Rainmaker: A Biography of John Ballance, Journalist and Politician (Heinemann Reed, Auckland, 1989); K R Howe Singer in a Songless Land: A Life of Edward Tregear (Auckland University Press, Auckland, 1991). Howe's fascinating book interprets Tregear's life as a creative effort to intellectually colonise and domesticate the "songless land" of New Zealand through his activities as a scholar of comparative Polynesian linguistics as well as in his model domestic life and his work as a dedicated civil servant. The lack of a comprehensive modern biography of Stout is a colossal gap in New Zealand historiography. 
the issue as well, but I cannot claim to be certain of that. In some ways Salmond's stance has affinities with McKenzie's famous Land Bill of $1892,{ }^{61}$ which introduced such public policy initiatives into Crown grants as mineral reservations, long-term leaseholds and lands reserved from sale ("marginal strips" or the "Queen's chain"). The New Zealand Liberal party ethos was essentially one of enlightened étatisme, which might characterise Salmond's leanings as well. (I confess to being a little uncertain as to where Salmond belonged on the political spectrum of the day.) Maybe Salmond saw it as simply self-evident that Maori should not be able to gain private title to navigable waters. His opposition may not so much have been to Maori as such, but rather private ownership: if Maori could get title to the bed of Lake Wakatipu the chances were that they would probably sell it and it would end up in private hands. If that was Salmond's reasoning, he can certainly be forgiven for thinking that Maori would be likely to sell, as at this time Maori were certainly still selling undivided shares to the Crown at low values and on a massive scale.

The Waikaremoana issue itself was to have a long history, which has by no means come to an end. (In fact Lake Waikaremoana figured prominently in the Waitangi Tribunal's Urewera regional inquiry, on which the Tribunal is soon expected to report.) Judge Gilfedder made an interim decision on the lake in August 1917. ${ }^{62}$ This related mainly to the Kahungunu/Tuhoe boundary. Final awards were made in 1918, following which the Crown, Tuhoe and Ngati Ruapani all appealed to the Native - now Maori - Appellate Court. The case then languished until the Crown appeals were finally dealt with, which was not (astonishingly) until 1944. This delay was due to a set of circumstances which were no one's fault in particular, but it is also certainly the case that the Crown was in no hurry to force the issue and was very unwilling to concede any kind of customary title. One serious problem for the owners was their extreme poverty and consequent inability to afford counsel. One lawyer who did agree to act for the owners (Charles Skerrett KC, an impressive personality) was lost to them when he became Chief Justice in 1926. While the issue was still disputed and under appeal the government went ahead with the Lake Waikaremoana power scheme which involved substantial impacts on the Waikaremoana shoreline and on lake levels.

None of this can be attributed to Salmond, needless to say. Salmond's legal opinions did however have the effect of giving the impression that title to the lake was uncertain, an uncertainty which the government can be fairly said to have exploited. When, finally, the Crown appeals were heard in 1944 the government continued to argue that the Native Land Court had no jurisdiction to deal with the matter. The Appellate Court gave the Crown arguments very short shrift, and had no hesitation in concluding that Lake Waikaremoana "can be considered Native customary land and that sufficient evidence was adduced to the Native Land Court upon which it could proceed to make

61 On McKenzie see Tom Brooking Lands for the People: The Highland Clearances and the Colonisation of New Zealand: A Biography of John McKenzie (University of Otago Press, Dunedin, 1997).

62 Lake Waikaremoana case (1917) 29 Wairoa MB 76. 
freehold orders". ${ }^{63}$ But the issue continued to drag on until the enactment of the Lake Waikaremoana Act 1971. Today the lakebed has the status of Maori freehold land, subject to a Crown lease, and is managed as part of Urewera National Park.

\section{SALMOND AND THE FORESHORE ISSUE}

Salmond believed that the Crown had title to the foreshore and that Maori should not be able to assert title to it. He based this view on the decision in Waipapakura $v$ Hempton, decided by the Supreme Court in 1914, in which Salmond had appeared for the Crown. Salmond's argument in this case raised issues that the Courts are still struggling with. His view was that Native title can only extend to high water mark: 64

The only land over which the Maoris never had any claim was land under tidal waters, and it is only in such waters that there could be non-territorial fisheries. The plaintiff's claim is for a non-territorial fishery in the tidal waters of the Crown. The land has belonged to the Crown since the Crown came to New Zealand. The principle that tidal waters belong to the Crown is in force here unaffected by the Treaty of Waitangi or Native land legislation. Native title is limited by high-water mark, and does not include tidal waters. It is illegal for the Crown to make a grant that would interfere with the public right of fishing and navigation: Attorney-General for British Columbia v Attorney-General for Canada.

The decision in Waipapakura arose out of an action in conversion brought by a Maori woman against a fisheries officer. The officer had seized the plaintiff's nets on the grounds that she was fishing unlawfully in breach of the Fisheries Regulations; the plaintiff argued that the seizure was itself unlawful as she was exercising a Maori fishing right protected by s 77(2) of the Fisheries Act 1908. The Supreme Court (Stout CJ) held, in essence, that the fishing rights protected by s 77(2) had to be sourced in statute.

In 1916 Salmond was asked for an opinion on native title to the foreshore at Napier. Salmond's view was very firm: ${ }^{65}$

The inner harbour, whether included in the Crown purchase or not, is tidal water and the limits of the Native customary title are high water mark. Whatever the title of the Natives may be to inland non-tidal waters they have no title to any part of the sea, whether land-locked or otherwise. This seems to have been determined by the Court of Appeal in Waipapakura v Hempton (1914) 33 NZLR 1065.

This arose out of an application for an investigation of title to Napier Inner Harbour (Te Whanganui a Orotu) heard initially by the Native Land Court sitting at Napier in $1916 .{ }^{66}$ Judge

63 Lake Waikaremoana case (1944) 8 Wellington ACMB 30.

64 Waipapakura v Hempton (1914) 33 NZLR 1065, 1067-8 (SC).

65 Salmond to Under-Secretary of Lands, 28 August 1916, copy on L 1, 29057 [Ahuriri lagoon], Archives New Zealand, Wellington.

66 See Te Whanganuia Orotu case (1916) 66-7 Napier MB 235-9. 
Gilfedder concluded that because this water body had been purchased by the Crown in 1851 and had been vested by the Crown in the Napier Harbour Board by statute the Land Court had no jurisdiction to deal with it. The position with regard to the inner harbour at Napier was complicated, as can be seen, by issues as to whether the Crown had extinguished the Native title (if any) either by purchase or by vesting in a third party - or by a combination of the two. Salmond thought that the inclusion of the harbour within the plan attached to the 1851 deed was a mistake, but believed in any event that this was irrelevant and "of no practical importance". Te Whanganui a Orotu belonged to the Crown in any case, given that the harbour "is tidal water and the limits of Native customary title are high water mark". If the case was appealed to the Native Appellate Court it was "important" that "the Crown should be represented". ${ }^{67}$ The Maori applicants did indeed take the matter to the Native Appellate Court, and instructed CB Morison KC to argue the appeal. Before deciding whether or not to accept the brief, Morison asked to be shown the original 1851 deed and attached plan in order to ascertain for himself whether the lagoon area had been included in the Ahuriri purchase. This provoked a flurry of interdepartmental correspondence as to whether Morison should be allowed to see the deed. Salmond decided that he could inspect it, but that he "should not, however, be permitted to make a copy of the Deed or make a list of the signatories". ${ }^{68}$ This is long before open government became the mantra, or pious fiction more accurately, that it is today. No record has survived of Morison's conclusions once he had inspected the original deed, but it does not seem unreasonable to infer that his scrutiny of the documents must have had a significant bearing on the decision made to abandon the appeal. In 1919 two of the appellants, Waka Pango and Aporo appeared at a sitting of the Native Appellate Court and formally withdrew their appeal. That was not the end of the Napier Inner Harbour saga by any means - in fact the issue is yet to be resolved.

\section{SALMOND AS JUDGE}

Salmond did not make any particular contribution to Maori land law as a judge, although his formidable grasp of the field did stand him in good stead on occasion. One of Salmond's best-known judgments is his dissenting opinion in Boyd $v$ Mayor of Wellington ${ }^{69}$ where Salmond defends the concept of deferred indefeasibility (that is, that a party registering a void memorandum should not be able to claim the full benefits of registration under the Land Transfer Acts) both in terms of principle and also in terms of reconciling apparently competing precedent. In support of the latter Salmond was able to show that the complex facts of the various appeals consolidated into the decision of the Judicial Committee in Assets v Mere Roihi were not incompatible with the concept

67 Ibid.

68 Salmond to Under-Secretary of Lands, 28 August 1916, L \& S 29057, Archives New Zealand, Wellington.

69 Boyd v Mayor of Wellington [1924] NZLR 1174 (CA). 
of "deferred indefeasibility". ${ }^{70}$ No doubt Salmond's solid grasp of statutory Maori land law contributed significantly to the analytical quality of this celebrated judgment.

\section{SALMOND'S LEGACY}

It is too early to fully assess Salmond's contribution to this field, which will require a fuller analysis of Salmond's opinions as Solicitor-General and of his various judicial decisions. My conclusions are impressionistic at this stage, and the impression that I have is that Maori issues and Maori land law were not central concerns or interests of Salmond's. His attentions as a scholar, writer and thinker were directed elsewhere. There were people who were interested intellectually in Maori customary law as law at this time, but Salmond was not one of them. He had a very clear and solid grasp of the statutory structure of Maori land law, no doubt acquired in the main during his work on the 1909 legislation, which he used to good effect in his opinions and some of his judgments. That aside, Salmond's main legacy seems to lie in the more narrow field of Maori claims to the foreshore and lakes, to which Salmond was both professionally (and probably personally) opposed, and which created a particular legacy and stance within the Crown Law Office. Further research and consideration should refine this broad assessment.

70 Assets Co Ltd v Mere Roihi [1905] 1 AC 176 (PC). 
